\title{
Correction to: PGC-1 a regulates airway epithelial barrier dysfunction induced by house dust mite
}

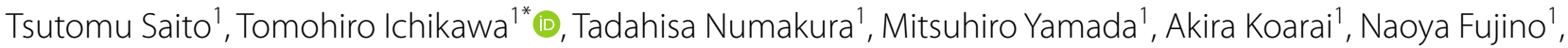
Koji Murakami', Shun Yamanaka', Yusaku Sasaki', Yorihiko Kyogoku², Koji Itakura ${ }^{3}$, Hirohito Sano', Katsuya Takita', Rie Tanaka', Tsutomu Tamada', Masakazu Ichinose ${ }^{2}$ and Hisatoshi Sugiura'

\section{Correction to: Respir Res (2021) 22:63}

https://doi.org/10.1186/s12931-021-01663-6

Following publication of the original article [1], we were notified that the supplementary file was incorrect.

The original article has been corrected.

\section{Author details}

${ }^{1}$ Department of Respiratory Medicine, Tohoku University Graduate School of Medicine, 1-1 Seiryo-machi, Aoba-ku, Sendai 980-8574, Japan. ${ }^{2}$ Department of Respiratory Medicine, Sendai City Hospital, Sendai, Japan. ${ }^{3}$ Department of Respiratory Medicine, Osaki Citizen Hospital, Osaki, Miyagi, Japan.

Published online: 08 March 2021

\section{Reference}

1. Saito T, Ichikawa T, Numakura T, Yamada M, Koarai A, Fujino N, Murakami K, Yamanaka S, Sasaki Y, Kyogoku Y, Itakura K, Sano H, Takita K, Tanaka R, Tamada T, Ichinose M, Sugiura H. PGC-1 a regulates airway epithelial barrier dysfunction induced by house dust mite. Respir Res. 2021;22:63. https ://doi.org/10.1186/s12931-021-01663-6.

\section{Publisher's Note}

Springer Nature remains neutral with regard to jurisdictional claims in published maps and institutional affiliations. original author(s) and the source, provide a link to the Creative Commons licence, and indicate if changes were made. The images or other third party material in this article are included in the article's Creative Commons licence, unless indicated otherwise in a credit line to the material. If material is not included in the article's Creative Commons licence and your intended use is not permitted by statutory regulation or exceeds the permitted use, you will need to obtain permission directly from the copyright holder. To view a copy of this licence, visit http://creativecommons.org/licenses/by/4.0/. The Creative Commons Public Domain Dedication waiver (http://creativeco mmons.org/publicdomain/zero/1.0/) applies to the data made available in this article, unless otherwise stated in a credit line to the data. 